\title{
Development of advanced air-blown entrained- flow two-stage bituminous coal IGCC gasifier
}

\author{
Nikolay A. Abaimov*, and Alexander F. Ryzhkov \\ Federal State Autonomous Educational Institution of Higher Education «Ural Federal University \\ named after the first President of Russia B.N.Yeltsin», 620002, 19 Mira street, Ekaterinburg, Russia
}

\begin{abstract}
Integrated gasification combined cycle (IGCC) technology has two main advantages: high efficiency, and low levels of harmful emissions. Key element of IGCC is gasifier, which converts solid fuel into a combustible synthesis gas. One of the most promising gasifiers is airblown entrained-flow two-stage bituminous coal gasifier developed by Mitsubishi Heavy Industries (MHI). The most obvious way to develop advanced gasifier is improvement of commercial-scale $1700 \mathrm{t} / \mathrm{d} \mathrm{MHI}$ gasifier using the computational fluid dynamics (CFD) method. Modernization of commercial-scale $1700 \mathrm{t} / \mathrm{d}$ MHI gasifier is made by changing the regime parameters in order to improve its cold gas efficiency (CGE) and environmental performance, namely $\mathrm{H}_{2} / \mathrm{CO}$ ratio. The first change is supply of high temperature $\left(900^{\circ} \mathrm{C}\right)$ steam in gasifier second stage. And the second change is additional heating of blast air to $900^{\circ} \mathrm{C}$.
\end{abstract}

\section{Introduction}

Coal is the most widespread kind of fossil fuel in the world. Issues of highly efficient and environmentally friendly usage of coal fuel will be relevant of at least several hundred years. One of the promising options for solving these problems is the integrated gasification combined cycle (IGCC) technology. Coal or other solid fuel is converted (gasified) into a combustible synthesis gas by special reactors called gasifiers. The large capacity (over 250 MW) IGCC structure includes entrained-flow type gasifier, because of their high unit performance. The IGCC efficiency depends largely on the gasifier operation parameters.

The paper aim is development of advanced air-blown entrained-flow two-stage bituminous coal IGCC gasifier. To achieve the aim it is necessary to accomplish the following tasks:

1) examine the gasifiers development international experience and choose the original design of commercially successful gasifier, based on which advanced gasifier will be developed;

2) create and verify the model to investigate the features of entrained-flow gasifiers and develop new designs;

3) modify the original gasifier to increase its efficiency and improve environmental performance using the verified model.

\footnotetext{
* Corresponding author: nick.sum41@mail.ru
} 


\section{$2 \mathrm{MHI}$ gasification technologies}

One of the most perspective and cost-effective entrained-flow gasification technology is the air-blown two-stage gasification. Using air blast instead of oxygen blast allows refusing from expensive air separation plant, and two-stage principle provides the efficiency of the air-blown gasifier on oxygen-blown unit level. A world leader in the air-blown entrainedflow two-stage gasification technology is Mitsubishi Heavy Industries (MHI) power engineering company. The company built the first Nakoso $250 \mathrm{MW}$ demonstration IGCC plant with air-blown entrained-flow gasifier in September 2007 [1]. The plant was owned by the Joban Joint Power Company and start commercial exploitation in April 2013 [2]. MHI needed to create experimental facilities fleet (table 1) of different scales and operating parameters gasifiers for development of commercial-scale air-blown entrained-flow twostage bituminous coal IGCC 1500-2000 t/d gasifier.

Table 1. Experimental air-blown entrained-flow two-stage MHI gasifiers

\begin{tabular}{|c|c|c|c|c|c|c|}
\hline Parameters & $\begin{array}{l}\text { Center } \\
\text { Institute } \\
\text { Power I }\end{array}$ & $\begin{array}{r}\text { Research } \\
\text { of Electric } \\
\text { lustry }[3,4]\end{array}$ & MHI, Ltd. [5] & $\begin{array}{l}\text { MHI } \\
\text { Nagasaki } \\
\text { R\&D } \\
\text { Center [6] }\end{array}$ & $\begin{array}{l}\text { IGC } \\
\text { Research } \\
\text { Association } \\
\text { [7] }\end{array}$ & $\begin{array}{l}\text { Clean Coal } \\
\text { Power R\&D } \\
\text { Company, } \\
\text { Ltd. [1] }\end{array}$ \\
\hline $\begin{array}{l}\text { Coal mass flow, } \\
\mathrm{t} / \mathrm{d}\end{array}$ & 2 & 3 & 8 & 24 & 200 & $1500-2000$ \\
\hline $\begin{array}{l}\text { Operation period, } \\
\mathrm{yr}\end{array}$ & $\begin{array}{l}1983- \\
1995\end{array}$ & 2004-NA & NA & $1998-2002$ & 1991-1996 & $2007-2012$ \\
\hline $\begin{array}{l}\text { Operating time } \\
\text { (total/ } \\
\text { continuous), hr }\end{array}$ & $\begin{array}{l}2220 / \\
\text { NA }\end{array}$ & NA & $\mathrm{NA}$ & $201 / \mathrm{NA}$ & $4770 / 789$ & $18788 / 2238$ \\
\hline $\begin{array}{l}\text { Number of } \\
\text { investigated } \\
\text { coals }\end{array}$ & 22 & 1 & NA & NA & 3 & 8 \\
\hline $\begin{array}{l}\text { Gasifier } \\
\text { dimensions } \\
\text { (height/ } \\
\text { diameter), m }\end{array}$ & $\begin{array}{l}5.85 / \\
0.3\end{array}$ & NA & NA & NA & $11 / 1.2$ & $\begin{array}{l}3.5 / 18 \\
\text { (estimated) }\end{array}$ \\
\hline Pressure, $\mathrm{MPa}$ & 2 & 2 & 0.1 & 2 & 2.7 & 2.7 \\
\hline Features & $\begin{array}{l}\text { A lot } \\
\text { of exp. } \\
\text { data }\end{array}$ & $\begin{array}{l}\text { Possibility } \\
\text { of a steam } \\
\text { supply }\end{array}$ & $\begin{array}{l}\text { Atmospheric } \\
\text { pressure }\end{array}$ & $\begin{array}{l}\text { Testing of } \\
\text { fuel supply } \\
\text { and } \\
\text { automatics }\end{array}$ & \begin{tabular}{l}
\multicolumn{2}{l}{ Resolves } \\
issue of \\
diffuser \\
slagging
\end{tabular} & $\begin{array}{l}\text { Converted } \\
\text { into } \\
\text { commercial } \\
\text { operation }\end{array}$ \\
\hline
\end{tabular}

The MHI gasifier operation principle is constructive separation of combustion and gasification regions. The gasifier is divided into two chambers (stages): combustion chamber (first stage) and gasification chamber (second stage). The chambers are connected by confuser-diffuser pinch to prevent ingress of the fuel mineral part from the first stage to the second one. The primary coal and char are tangentially fed into the combustion chamber to create a cyclonic effect which allows intensifying of the combustion process. Besides this effect favors to create a molten slag film on the first stage walls, the slag gradually flows down into the slag bath. The coal particle carbon on the chamber walls burn out much more rapidly than in the air flow as it airspeed increases substantially. Further, the conversion gas products pass into the gasification chamber, where they are mixed with a secondary coal. There occurs a so-called chemical quenching, i.e. hot gas products of complete combustion are cooled as a result of the endothermic reactions between $\mathrm{CO}_{2}, \mathrm{H}_{2} \mathrm{O}$ and coal carbon. The secondary coal char is separated from the synthesis gas after the second stage by the cyclone-separator. Then, the char is fed into the gasifier first stage for combustion that improves the carbon conversion rate of the gasifier. 


\section{Model verification}

The development of such gasifiers requires costly experimental studies and high precision mathematical modeling. There is very limited number of the experimental installations, which are capable to obtain sufficient results for modeling and development. However, there are many approaches to the entrained-flow gasifiers modeling. Over recent decades Computational fluid dynamics (CFD) method has become increasingly popular. The CFD approach has broad functionality and high accuracy.

To confirm the applicability of the our CFD model (described in [8]) for the MHI-type gasifiers calculations we carried out model verification using experimental data which was obtained at MHI 2 t/d gasifier [9]. Verification results are shown in Figure 1 and Table 2.

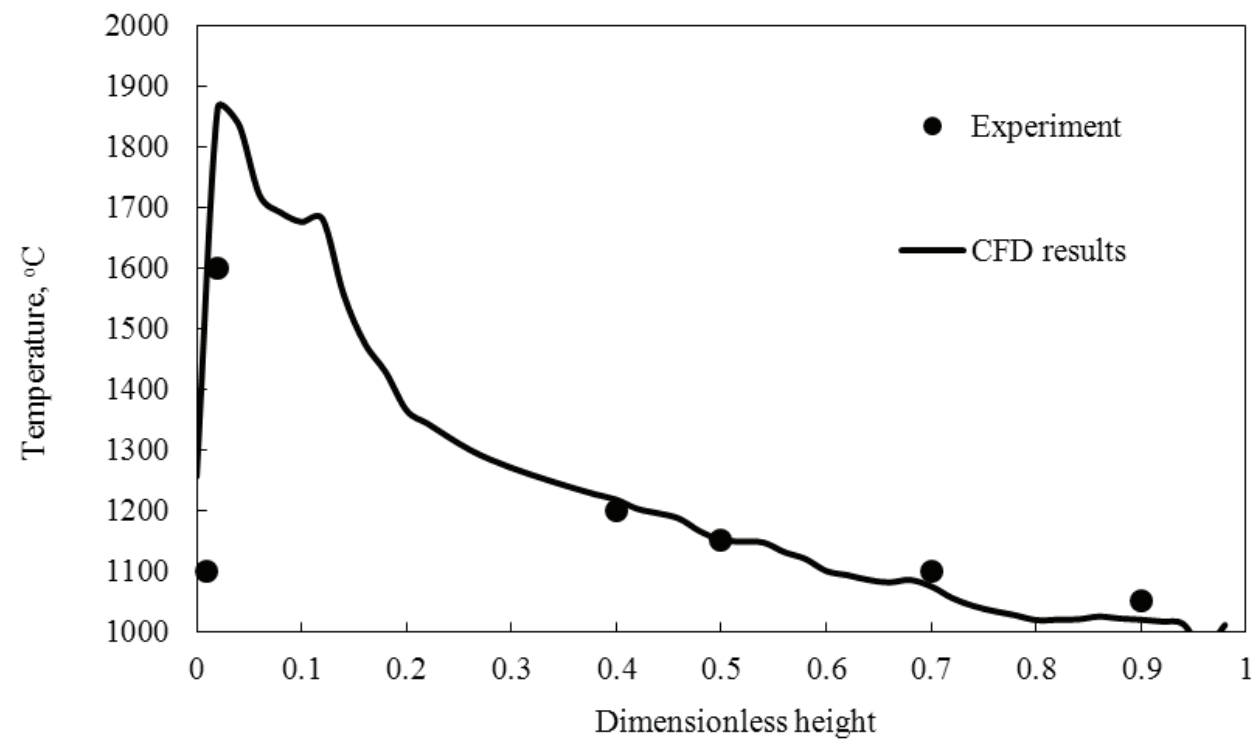

Fig. 1. Comparison of experimental [5] and CFD calculation temperature along gasifier height.

Table 2. Comparison of experimental [5] and CFD calculation syngas components concentrations.

\begin{tabular}{|c|c|c|}
\hline Syngas component concentrations, \% vol. & Experiment & CFD results \\
\hline $\mathrm{H}_{2}$ & 7.3 & 6.9 \\
\hline $\mathrm{CO}$ & 20.2 & 21.5 \\
\hline $\mathrm{CO}_{2}$ & 6.3 & 5.1 \\
\hline $\mathrm{H}_{2} \mathrm{O}$ & 2.0 & 3.7 \\
\hline
\end{tabular}

Verification results show that used CFD model satisfactorily meets the requirements of adequate MHI-type gasifiers modeling. Thus, this model will continue to be used in the development of the advanced gasifier.

\section{Gasifier development}

When creating high-efficiency advanced air-blown entrained-flow two-stage IGCC gasifier the most obvious way is to upgrade the existing commercial MHI gasifier. The modernization consists in several fundamental technical solutions:

1) steam supply into gasifier second stage;

2) blast air extra heating; 
3) optimization of the gasifier design, in particular the location of the steam supply points into the second stage taking into account the control mechanisms of the gasification process, used earlier in the paper [8].

The first two points are considered in this paper. Implementation of the third point requires additional experimental and computational data, so it will be resolved in future studies.

With increasing $\mathrm{CO}$ content relative to hydrogen in the synthesis gas the fuel nitrogen oxides quantity produced by combustion is reduced [10]. To increase the synthesis gas hydrogen concentration the steam is supplied into the gasifier second stage, and the heat required for the steam gasification is compensated by additional heating of the blast air. This improves the cold gas efficiency (CGE) of the gasifier, the carbon conversion rate and the synthesis gas hydrogen concentration to the required level.

Three-dimensional view and two-dimensional sections of the modernized MHI gasifier are presented in Figure 2.

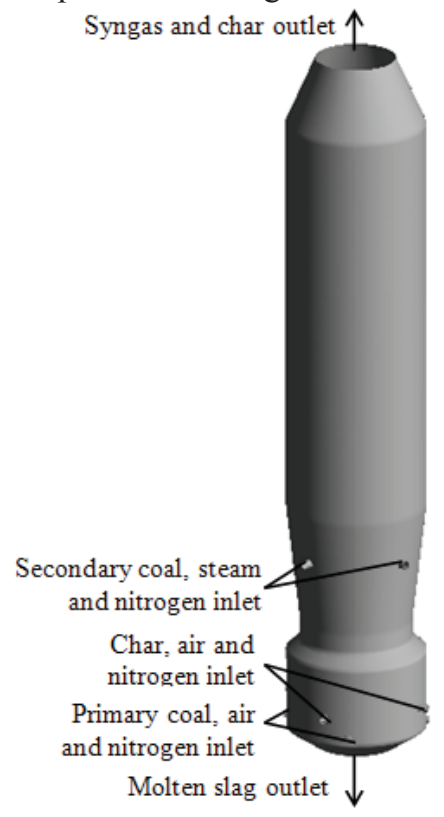

a)

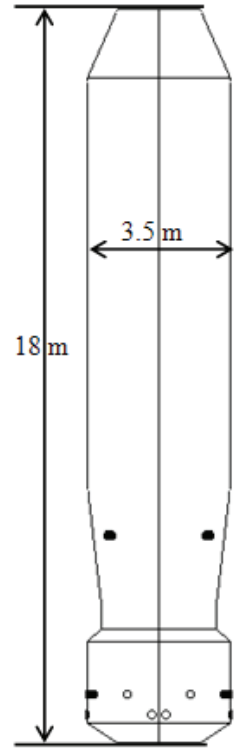

b)

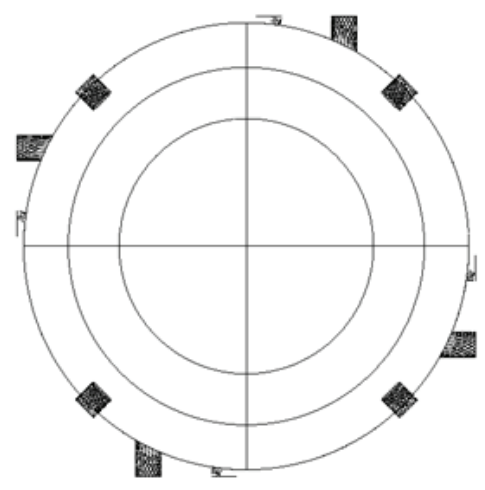

Fig. 2. Modernized gasifier: a) 3-D view; b) longitudinal section; c) transverse section.

Used air stoichiometric factor ensures the process flow near the point of thermodynamic equilibrium taking into account the amount of supplied steam. The blast air is enriched with oxygen to $25 \%$. Transport of coal and char is carried out by nitrogen. The second stage steam is fed at a rate sufficient to ensure that the synthesis gas temperature at the gasifier outlet is approximately $1100-1200^{\circ} \mathrm{C}$. The blast air and steam have a temperature of $900^{\circ} \mathrm{C}$. The compositions of the synthesis gas produced in the original (MHI) and modernized (UrFU) gasifier designs are given in Table 3.

Table 3. Comparison of MHI [1] and Ural Federal University (UrFU) gasifier operation parameters.

\begin{tabular}{|c|c|c|c|c|c|c|}
\hline \multirow{2}{*}{ Gasifier } & \multicolumn{5}{|c|}{ Dry syngas composition, \% vol. } & \multirow{2}{*}{ CGE, \% } \\
\cline { 2 - 5 } & $\mathrm{CO}$ & $\mathrm{H}_{2}$ & $\mathrm{CO}_{2}$ & $\mathrm{CH}_{4}$ & $\mathrm{~N}_{2}$ & \\
\hline MHI & 30,5 & 10,5 & 2,8 & 0,7 & 55,5 & 77,2 \\
\hline UrFU & 27,8 & 16,8 & 4,78 & 2,4 & 46,3 & 84,9 \\
\hline
\end{tabular}


Modernization of the MHI gasifier improves the heating value of the produced synthesis gas, increases the $\mathrm{H}_{2}$ concentration, reduces the $\mathrm{CO}$ concentration and increases gasifier CGE.

\section{Conclusion}

The proposed modernization (steam supply into gasifier second stage and blast air extra heating) of the MHI-type gasifier, conducted with the use of verified CFD model, improves the $\mathrm{CGE}$ and the ratio $\mathrm{H}_{2} / \mathrm{CO}$ of the produced synthesis gas. A further way of the gasifier improving is optimization of location and directions of coal and steam feed into the gasifier second stage.

This work was carried out at the Ural Federal University and financially supported by the Russian Science Foundation (project no. 14-19-00524).

\section{References}

1. M. Susaki, Y. Takashima, H. Ishii, Y. Kitagawa, O. Shinada, T. Hashimoto, Mitsubishi Heavy Industries Technical Review, 46, 5-8 (2009)

2. K. Sakamoto, Gasification and Syngas Technologies Conf. (2014) http://www.gasificationsyngas.org/uploads/eventLibrary/2014_13.3_Mitsubishi_KS_UPDATED.pdf

3. S. Hara, J. Inumaru, M. Ashizawa, K. Ichikawa, JSME Int. J. Series B Fluids and Thermal Engineering, 45, 518-522 (2002)

4. S. Hara, Second Int. Freiberg Conf. on IGCC and XtL Technologies (2007) http://tufreiberg.de/sites/default/files/media/institut-fuer-energieverfahrenstechnik143/publikationen/2007-5-4.pdf

5. C. Chen, T. Miyoshi, H. Kamiya, M. Horio, T. Kojima, The Canadian J. of chem. engineering, 77, 745-750 (1999)

6. O. Shinada, A. Yamada, Y. Koyama, Energy Conversion and Management, 43, 12211233 (2002)

7. S. Araki, Y. Hanai, J. of the Japan Institute of Energy, 75, 839-850 (1996)

8. N. A. Abaimov, A. F. Ryzhkov, Thermal Engineering, 62, 767-772 (2015)

9. H. Watanabe, M. Otaka, Fuel, 85, 1935-1943 (2006)

10. T. Hasegawa, Energies, 3, 335-449 (2010) 